\title{
A Conceptual Study on Islamic Corporate Governance Model in Curtailing Bank's Fraud
}

\author{
Ali Danladi Yusuf, Umar Ahmad, Mohammed Shahril Bin Ahmad Razimi \\ Islamic Business School, College of Business, University Utara Malaysia, Sintok, Kedah State, Malaysia \\ Email address: \\ aliyusufdanladi@gmail.com (A. D. Yusuf), ahmad.u2005@gmail.com (U. Ahmad), sharil@uum.edu.my (M. S. B. A. Razimi)
}

\section{To cite this article:}

Ali Danladi Yusuf, Umar Ahmad, Mohammed Shahril Bin Ahmad Razimi. A Conceptual Study on Islamic Corporate Governance Model in Curtailing Bank's Fraud. International Journal of Economics, Finance and Management Sciences. Vol. 4, No. 6, 2016 , pp. 357-361. doi: $10.11648 /$ j.ijefm.20160406.17

Received: October 18, 2016; Accepted: October 31, 2016; Published: November 11, 2016

\begin{abstract}
The paper intends to discuss the concepts, framework, structure of fraud, and its two contending theories i.e. Fraud Triangle Theory and Fraud Diamond Theory. The paper also intends to analyse the concept of Islamic corporate governance, its theories and the popular theory of Shariah Enterprise Theory (S.E.T), which if properly implemented and giving a sound attention, the issue of fraud in Islamic banks will be a thing of the past. After the extend literature review this paper proposed model as re-examined by some scholars, to see whether the model is viable in today's multi-faith, and multicultural society of 21 th century and the likely challenges it might face.
\end{abstract}

Keywords: Fraud, Fraud Triangle Theory, Fraud Diamond Theory, Corporate Governance, Islamic Corporate Governance, Shariah Enterprise Theory

\section{Introduction}

Fraud is one of the numerous problems of today's business world. More so, the higher incidence of fraud within the banking sector has become a global phenomenon that needs urgent solution. This is in view of the enormous sum of money involved and its adverse implication on the global economies. (18) sees fraud as a crime of deceiving in order to get money or goods illegally. Financial frauds everywhere are the bane of economic development, which harms the economies in no small measure (33). (6) argues fraud is one of the reasons for the poor economic performance and rising poverty in most developing countries.

Although fraud is a worldwide phenomenon and nations have suffered severe losses financially (12). Financial fraud is a significant threat facing nations businesses and the individuals, once committed in any sector of the economy; it has a far reaching effect on the entire economy this is due to the fact that it inflicts huge financial loss to the economy. For instance, more than 1 of 10 companies worldwide surveyed reported their companies as having experience a significant fraud cases in the last two years. In fact the level of fraud reported by the chief executives remained largely unchanged over the past six years from $13 \%$ in 2008 to $12 \%$ in 2014
( $13^{\text {th }}$ Global fraud survey).

With the global statistics carried out between Nov 2013 and Feb, 2014 shown in table 1, the global marketers research agency, conducted the project with senior decision/makers of the corporate governance structure, with responsibility for tackling fraud, the above figures have shown to us that fraud is a global cancer to the world economies.

Table 1. Global Statistics of Fraud.

\begin{tabular}{lll}
\hline \multicolumn{3}{l}{ Countries with increased incidence of fraud from $\mathbf{2 0 1 4}$} \\
\hline S/N & Country & \% increase \\
\hline 1 & USA & $16 \%$ in 2014 up from $8 \%$ in 2012 \\
2 & China & $8 \%$ in 2014 up from $4 \%$ in 2012 \\
3 & Japan & $10 \%$ in 2014 up from $6 \%$ in 2012 \\
4 & Russia & $16 \%$ in 2014 up from $10 \%$ in 2012 \\
5 & Germany & $26 \%$ in 2014 up from $8 \%$ in 2012 \\
Countries & with significant increase of incidence of fraud from 2014 more \\
than $25 \%$ & \\
1 & Egypt & $44 \%$ in 2013 \\
2 & Nigeria & $30 \%$ in 2013 \\
Countries & with less incidence of fraud from 2013 \\
1 & Saudi Arabia & $4 \%$ \\
2 & Australia & $13 \%$ \\
3 & Argentina & $2 \%$ \\
\hline
\end{tabular}

Source: The Global Market research Agency 2014 
Furthermore, not only conventional banking system is suffering from fraud, Islamic Banks are also disposed to losses, or even failures, which can be as a result weaknesses in their corporate governance mechanism (23). Some of the renown cases of fraud in Islamic banking system includes; South African Islamic Bank collapsed in 1997, the demised of Ihlas Finance House in Turkey in 2001, and various cases of fraud which led to losses at Dubai Islamic Bank between 2004 to 2007, all these cases serve as indicator for the importance and the need for a sound corporate governance in Islamic banks (15). Islamic Banks need to build prudent corporate governance, even though the Islamic values protect the right of the Stockholders (9).

Based on the issue highlighted above, this paper aim to proposed Islamic Corporate Governance Model in Curtailing Bank's Fraud particularly in the context of Nigeria, which can serve as a references for future research.

\section{Literature Review}

\section{Definition of Concepts and Theories \\ Fraud definition}

Fraud has been widely defined in literature by scholars and experts. Fraud used as a noun, means, wrongful or criminal deception intended to result in financial or personal gains. According to (21) fraud is an act or course of deception, an intentional concealment, omission, perversion of truth to gain unfair advantage, induce another to part with some valuables items, or inflict injury in some manners. Additionally, Association of Certified Fraud Examiners (ACFE) (1999) defined fraud as the use of ones occupation for personal enrichment through deliberate misuse, misapplication or employment of organisational resources or assets. Federal Bureau of Investigation (FBI) (1984) defined fraud as fraudulent conversion and acquisition of money or property by false pretence.

\section{Fraud Triangle Theory}

The origin of the Fraud Triangle Theory (FTT) dates back to the work of (30), who came up with white-collar crime, Cressey was one of the Sutherland former students. (11) in his research work which later become known as the fraud triangle theory (FTT), emphasizing on talk on pressure, opportunity, and rationalisation as its core elements. Fraud in the corporate world has been deeply studied, which result in coming up with well enhanced theoretical framework. The general view expressed in many of this fraud related studies, is that fraud prevention is more costly effective than fraud detection. It is less expensive and more effective to prevent fraud from happening than detect it after it occurs. Sometimes by the time the fraud is discovered, the money is unrecoverable, or chance of recovering the full amount of the loss is so slim (1). It is good for organization to identify those factors that always lead to fraud, before making any effort to reduce fraud, find out who are the fraudsters, when and why fraud is committed (31).

Fraud Diamond Theory

(35) strongly believed that the Cressey fraud triangle theory has to be improved, hence they introduced additional element to the one of (FTT). Based on this, additional element which they called Capability, they come up with what is now being regarded as the fraud Diamond theory (FDT). According to them capability is very important for any fraud to take place. However, recent happening in the corporate world, with regard to fraud, has shown that the two theories are grossly inadequate to explain the motivation fraudster. Although, Cressey fraud triangle was supported and used by Audit Regulators-(ASB and IAASB), critics have argued that the model cannot solve the fraud problems alone because the two sides of the fraud triangle, e.g. pressure, or rationalization cannot be easily observed (13), as cited in (22). Again the fraud diamond theory by (35), also has its shortcoming, though it added the fourth element, capability to the FTT and filled the gap of other theories of fraud, the FDT model alone is inadequate tool for investigating and detecting frauds (14).

Empirical Cases of Fraud in the Banking Sector

In August, 1995, Citi bank had problem with outsiders breaking in to their system. A $\$ 10$ million computer fraud against Citi bank was the first successful penetration by a hacker in to the system which transferred trillion of dollars a day around the world of the $\$ 10$ million dollars illegally transferred $\$ 400,000$ was not found (36).

In August, 2000, UK, Police have arrested three men in connection with an attempt to defraud the Egg Banking Plc. The bank was reportedly the target of an effort to obtain money via fraudulent accounts but no money was stolen and the bank stressed that none of its computer system had been breached. The fraudsters had attempted to obtain thousands of pounds (GBP) via multiple saving accounts and loans. These men are allegedly part of an organised crime syndicate (Internet Business News, 2000).

In April 2010, a fire alarm company in US lost more than $\$ 110,000$ in one month, when hackers stole the firm online banking credentials and drained its payroll account. Over the course of the previous days, someone had approved two batches of payroll payment, one for $\$ 45,000$, and another for $\$ 67,000$. A few days the chief executive was informed by the bank that it was the (internet) address that was used to process the payments and online banking user name \& password (Fire Alarm Firm Burned, 2010).

All the above incidences are clear empirical cases to show how the two cited fraud theories, i.e. FTT and FDT work in the practical situations, despite their short comings, in mitigating fraud in banks. This brings the issue of looking for a sound and proper model of corporate governance, as alternative to existing western model of corporate governance, which brought about cases of scandals, fraud and other corporate failures. Thus next subsection will explained on the Islamic Corporate Governance.

Islamic Corporate Governance

Timur Kuran, a leading academic on Islamic economics, states that classical Islamic law does not recognized the concept of corporation, (24). Early Muslims were only aware of the concept of Waqf, Ibn Battuta, a famous Muslim 
traveller; describe the importance of Waqf, which include provision of drinking water, assistance to the travellers, financing of pilgrimage, and help to impoverished brides.

Despite non recognition of concept of corporation at early stage of Islamic period, an attempt toward forming Islamic corporate governance has been made by different scholars. The holy Quran and Hadith provide principles and guidelines about how decision-making should take place in an Islamic context (26). According to Wolfensohn, former World Bank president; corporate governance is about promoting corporate fairness, transparency, and accountability (3). OECD states that corporate governance can be defined narrowly as the relationship between a company to its shareholders, or more broadly relation to the society. The concept of Islamic Corporate Governance (ICG) is no difference with that of OECD, except that ICG used the premise of Islamic socioscientific epistemology premised on divine, oneness of GOD (17).

One of the most unique features of Islamic bank corporate governance is Shari'ah compliance and the existent of Shari'ah board, which ensures that all transactions are performed in accordance to Shari'ah law. Islam corporate governance structure differs from conventional corporate governance in the standardization of rules which must obey the Shari'ah rules as stated in the Holy Qur'an, where the governance structure should meet the expectation of Muslim Ummah. The Islamic corporate governance structure has an obligation towards the community, the employees, and related parties of an organization (25). The staff in the Islamic bank should act according to Islamic principles and adhere to the teaching of Islam. Accounting standard in Islamic bank, should consider that Islamic banking is interest free banking, the bank cannot sources fund to trade in non halal activities. The governance structure of Islamic bank needs banks to establish Shari'ah supervisory board (SSB), and the internal control which support it. There is the primary section of Shari'ah governance framework, which includes: the board of directors, the management board and Shariah advisory board. Islamic corporate governance takes into account interest of all stakeholders. Good Shari'ah governance ensures Islamic bank finance growth (Hassan, 2009). Based on that the next subsection discussed on Islamic corporate governance theories

\section{Islamic Corporate Governance Theories}

Islamic corporate governance, being a new if compare with western type, yet it played a great role in shaping the minds of Muslim scholars, economics and professionals alike, the aim of ICG is Maqasid Shariah, which was developed by a famous Muslim scholar called Al-Ghazali, it refer to the protection of the welfare of the people, including their faith, life, intellect, posterity \& wealth (17). So, the main proponent of ICG theories originated from the following postulation; a) proprietary theory, this refers to ownership right, when one possess owns, or hold exclusive right to something e.g. as proprietor; b) Entity theory, the basic assumption that all economics activities conducted by $\mathrm{s}$ business man is separate from that of its owners. The theory is based on the idea that all of the company activities can and will be accounted for independently from the owners activities; c) Enterprise Islamic theory, this theory emerged due to failures of the above two theories, proprietary and entity theories. Theory of business Enterprise is an economic book written by Thorstein Veblen, published in 1904. This theory is about social and economic goals that stresses GOD, in all its structure, its developed in to what is now called S.E.T., Shariah Enterprise Theory, which is all about God, Human and Environment. The theory went in to lot of transformations. (20) talked more on the theory in his books, (Origin of Mohammadeen Jurisprudence, and Institution to Islamic Law).

The theory was expanded by another scholar called, (16), in his book Shariah, Theory, Practice \& Transformations. The book discussed in details more on, Maqsid -Shariah, all the four Schools i.e. Shafia, Malikia, Hanafia and Hambalia. The S.E.T. theory has as its core objectives; everything belong to ALLAH, and people are Jusamaht (God trustees on earth), human, environment has to be protected from air and gas pollution. It stresses spiritual values, justice, honesty, accountability (Amanah, Istiqamah,). S.E.T. was developed to replace entity theory. The S.E.T. theory is now being widely adopted in most Islamic countries in banks, and other corporate organizations, especially Indonesia, Malaysia, Oman, etc.

\section{Model and Bank Fraud}

The proposed model emerged from Shariah Enterprise Theory, which says governance is purely base on shariahcompliance, accountability, fairness, disclosure and transparency, all tend to picture a well encompassing structure, other governance variables of the model include; a) Board size, members competence, b) Independence of the management, c) Committees structure, d). Professionalism and e). Confidentiality. Good and sound Islamic corporate governance will result to efficient capital allocation by managers allows for the maintenance of supervision (BCBS, 2010). It is a mistake to believe the Islamic banks do not need to have prudent corporate governance just because of Islamic values system protect the right of the shareholders (9), Islamic banks are no less dispose than conventional banks to losses or even failures, which can result from corporate governance breaches e.g. of recent some Islamic banks were found with fraud not because they were not shariah compliance but due to staff negligence (2). The collapse of the Islamic Bank of South Africa in (1997), the demise of Ihlas Finance House in Turkey in 2001 and Dubai Islamic bank losses between 2004 to 2007, all serves as reminder of the importance of sound model of ICG for banks.

Islamic Good Corporate Governance Shari'ah lies under the "Shari'ah Enterprise Theory" (S.E.T), which has more concern with wider stakeholders which include God, human and nature. S.E.T. equalizes between material and spiritual values synthesizes between egoistic value and altruistic value which in Shari'ah are realized by a form of worship. The worship itself is a form a religious spiritual process of purification of the owner of the property by doing the zakat. 
Ownership in Islam is seen as trust, whereas, the part of ownership trusted contain other people's right and human obligation to share their ownership in the form of zakat, in accordance with Shari'ah rules (Rahmatan-lil'alamin).

In the perspective of Islam, corporate governance actually identified long ago since the emergence of Islam. Thus, the need for principle of corporate governance is not a brand new thing by the Muslim Ummah. The Islamic economic system rapidly develops when Islamic culture existed long ago (4). Generally, the principal and concept of good corporate governance consist of fairness, transparency, accountability and responsibility which were also found in fundamentals of Shari'ah law. However, there are fundamental difference objectives between Shari'ah based and conventional base; therefore, there was different mechanism and tools requested by good corporate governance (9).

The objective of Shari'ah is to increase human welfare, which consist of five factors; to take care of religion, to take care of soul, to take care of life, to take care of sense, to take care of their generation and to take care of wealth. Wealth is the last position on the five objectives of Shari'ah because if wealth is placed in the first priority. It will tend to increase injustice imbalance and at last affecting the welfare. In contrast, conventional economic system places the main objective to achieve the maximization of incoming materialism or known as utilitarianism (10).

According to the S.E.T theory, God is at the centre i.e. He is the highest stakeholder. Human aspect is divided into two; direct stakeholders i.e. those that contribute equity and indirect stakeholders i.e. those that did not contribute anything but have a stake in the company through issuance of zakat. While under nature, the physical environment of the company and the use of energy from the nature, to sum up, nature requires prevention, preservation and pollution of the environment.

The concept of ownership in Islam as stated in the Qur'an, which says the ownership is absolutely individual by God. Anything's that are owned by a human is only custodian, trusted or Amanah from God. Which are needed to be governed for the welfare of Rahmatun-lil-Alamin which says human must create and distribute wealth for the whole universe (32). Human is called "Khalifatul fil Ard" which human are representative of God (32). The duty of Khalifa requires human to perform the role appropriately from guidance of Allah which gives him the task and authority.

\section{Conclusion}

Corporate governance refers to the relationship between the corporation and its constituents. the ICG model proposed that its constituents are wider, due to the emphasis that shariah law places on property and contractual right, showing that, while the conventional concept of CG is what is termed as "shareholder-centric", the main focus of ICG model is wider which extend to customers, competitors, suppliers, and employers, thus, the model more in line with the "stakeholders theory of CG".
Moreover, the strong focus of shariah law is on ethics, accountability, and transparency allows ICG to be consistent with the OECD principles on CG. Theoretically, the concept of ICG is quite stable \& in line with different theorists that stressed corporate social responsibility (CSR). A good sound, well-articulated model, with proper plans and supervision from (SSB), in each Islamic bank the ICG model is bound to reduce cases of fraud in banks.

Therefore, this paper discussed and proposed a model of Islamic corporate governance as adopted by (28). It's expected that if this model can be validated in Islamic banking industry and other conventional banks particularly in the context of Nigeria the issue of Fraud could things of the past. And this model will add value to theory and practitioners.

\section{References}

[1] Abdullah R. \& Mansor, N. (2015). Fraud Triangle Theory and fraud Diamond through understanding of the convergent \& divergent for future research.

[2] AbdulRahman, N. (2009). Bank Fraud: Perception of Bankers in Qatar.

[3] Abu-Tapanjeh, Abdulsalam Mohmoud (2008), Corporate Governance from the Islamic perspective: A comparative analysis OECD principles, critical perspective on Accounting.

[4] Agustiano, (2008) The Genesis of Islamic Economics, Revisited.

[5] Ahmad, A. (2009). Identity Theft: A study on fraud prevention initiative at local Islamic banks.

[6] Aina, K. (2004) The role of auditors in fraud detection, prevention and reporting in Nigeria.

[7] Aina, K. (2004). Financial crime implication for the Capital Market and insurance Sub-Sector. Journal of Economic Crime. Vol. 3, 182-188.

[8] Ali Hakami, (2011). Fraud prevention in Saudi Arabia.

[9] Chapra, M. U. \& Ahmed, H. (2002). Corporate governance in Islamic institution.

[10] Chryssides and Kaler, (1993) An Introduction to Business Ethics.

[11] Cressey, D.R. (1950). The criminal violation of financial trust. American Sociological Review.

[12] Dagaci, (2011) Fraud a significant threat facing government business and individuals in Nigeria.

[13] Dorminey, J., Flemina A., Kramacher, M. \& Riley, R. (2010). Beyond the fraud triangle. The CPA Journal.

[14] Gbegi D. O. and Adebisi, O. (2013). The new fraud Diamond model- How it can help forensics Accountants in fraud investigation in Nigeria.

[15] Hafeez, M. M (2013): An Analysis of Corporate Governance in Islamic and Western Perspectives: International Journal of Business Economics and Law, Vol. 2, Issue 3. 
[16] Hallaq, (1984) Was the Gate of Ijtihad Closed? A critical analysis of the Schacht Argument and contemporary.

[17] Hasan, Z. (2008). Corporate governance from Western and Islamic perspective; conference paper presented $\mathrm{t}$ annual London conference on money, economy, and management,3-4 July 2008, Emperical college, South Kensington, United Kingdom.

[18] Hornby, (2001), Fraud and financial crime prevention, and control in Nigeria.

[19] Iqbal, Z., and Abbas, M. (2004). Stakeholders model of governance in Islamic economic systerms, Islamic Economics Studies. 11(2)

[20] Joseph Schacht, (1950) An introduction to Islamic law.

[21] Kalubanga, M., Kakwezi, P., \& Kayiize, D. (2003). The effect of fraud in procurement. International Journal of Business and Behioviral Sciences, 3.

[22] Kassem R., \& Higson, A.W (2012). The new fraud triangle model. Journal of Emerging Trends in Economic and Management Sciences, 3(3), 191-5.

[23] Khir, K., Gupta, L., \& Shanmugan, B. (2008). Islamic banking: A practical perspective. Malaysia: Pearson Malaysia.

[24] Kuran, T. (2005). The absence of the corporation in Islamic law: Origin and persistence. American Journal of Comparative Law, 53, 785-834.

[25] Lewis, M. (2005). Islamic corporate governance, Review of Islamic Economics, 9(1), 5-29.
[26] Lewis, M. (2006). Accountability and Islam; conference paper presented at $4^{\text {th }}$ conference on Accountancy in transition, Adelaide, 10-12 April, 2006. Netto, (2005). Islamic bank Woesh high light problems.

[27] Minhas, H. I. (2012). Shariah corporate model (SGM) and its four basic pillars. Islamic Finance News Malaysia, April $18^{\text {th }}$ 2012.

[28] Mohammed Ariff, (2011) Islamic Banking in Malaysia.

[29] Rashidah, A., Inda S., \& Khair A. (2014). Fraud in Islamic bank Malaysia: Effectiveness of fraud prevention techniques in Malaysia Islamic banks.

[30] Sutherland, (1939) Differential Association Theory - 1950, .

[31] Thanasak, R, (2013). The fraud factors, Internal Journal of Management.

[32] Triyuwono, (2007) Smart Shariah Accounting, (Shariah Enterprise Theory),Testing a model of Islamic Corporate Financing.

[33] Walker, (2009) A review of corporate governance in UK banks.

[34] William K. Black. (2005). The Best way to Rob a Bank is to own one.

[35] Wolfe, D. T. \& Hermanson, D.R. (2004). The fraud diamond considering the four elements of fraud. The CPA Journal, 74(12).

[36] Yang, (1979) Crazy Eddie fraud/ white collar fraud (Tax fraud). 